\title{
Model evaluation of marine primary organic aerosol emission schemes
}

\author{
B. Gantt ${ }^{1}$, M. S. Johnson ${ }^{1, *}$, N. Meskhidze ${ }^{1}$, J. Sciare ${ }^{2}$, J. Ovadnevaite ${ }^{3}$, D. Ceburnis ${ }^{3}$, and C. D. O'Dowd ${ }^{3}$ \\ ${ }^{1}$ North Carolina State University, Raleigh, NC, USA \\ ${ }^{2}$ Laboratoire des Sciences du Climat et de l'Environnement, Gif-sur-Yvette, France \\ ${ }^{3}$ School of Physics and Centre for Climate and Air Pollution Studies, Ryan Institute, National University of Ireland Galway, \\ University Road, Galway, Ireland \\ * now at: NASA Ames Research Center, Moffett Field, CA, USA
}

Correspondence to: N. Meskhidze (nmeskhidze@ ncsu.edu)

Received: 23 April 2012 - Published in Atmos. Chem. Phys. Discuss.: 23 May 2012

Revised: 16 August 2012 - Accepted: 2 September 2012 - Published: 21 September 2012

\begin{abstract}
In this study, several marine primary organic aerosol (POA) emission schemes have been evaluated using the GEOS-Chem chemical transport model in order to provide guidance for their implementation in air quality and climate models. These emission schemes, based on varying dependencies of chlorophyll $a$ concentration ([chl $a]$ ) and $10 \mathrm{~m}$ wind speed $\left(U_{10}\right)$, have large differences in their magnitude, spatial distribution, and seasonality. Model comparison with weekly and monthly mean values of the organic aerosol mass concentration at two coastal sites shows that the source function exclusively related to [chl $a$ ] does a better job replicating surface observations. Sensitivity simulations in which the negative $U_{10}$ and positive [chl $a$ ] dependence of the organic mass fraction of sea spray aerosol are enhanced show improved prediction of the seasonality of the marine POA concentrations. A top-down estimate of submicron marine POA emissions based on the parameterization that compares best to the observed weekly and monthly mean values of marine organic aerosol surface concentrations has a global average emission rate of $6.3 \mathrm{Tg} \mathrm{yr}^{-1}$. Evaluation of existing marine POA source functions against a case study during which marine POA contributed the major fraction of submicron aerosol mass shows that none of the existing parameterizations are able to reproduce the hourly-averaged observations. Our calculations suggest that in order to capture episodic events and short-term variability in submicron marine POA concentration over the ocean, new source functions need to be developed that are grounded in the physical processes unique to the organic fraction of sea spray aerosol.
\end{abstract}

\section{Introduction}

Recently, there have been several studies attempting to parameterize the emissions of marine primary organic aerosols (POA) (O'Dowd et al., 2008), estimate their concentrations in the marine boundary layer (Vignati et al., 2010), and evaluate their impact on cloud condensation nuclei (Roelofs, 2008; Fuentes et al., 2011; Meskhidze et al., 2011; Westervelt et al., 2012) and indirect forcing (Gantt et al., 2012). A few of these emission schemes have been evaluated against satellite-based aerosol optical depth (AOD) and ship-based concentration observations (Lapina et al., 2011), but the majority have not been compared to measurements from hourly to monthly temporal resolutions to enable a process-based evaluation. As the emissions of marine POA have been described as globally significant (Spracklen et al., 2008; Gantt et al., 2009) and shown to contribute to an increase in modelpredicted regional surface CCN concentrations by over $20 \%$ when treated as additional aerosol number externally-mixed with sea-salt (Meskhidze et al., 2011; Westervelt et al., 2012), there is a need for a process-based, comprehensive evaluation of the parameterizations before their widespread implementation into climate and air quality models.

Marine POA emission parameterizations fall into two main groups: (1) emission rates exclusively related to chlorophyll $a$ concentration ([chl $a]$ ) and (2) emission rates linked to sea spray emissions through the calculation of the organic mass fraction of sea spray aerosol $\left(\mathrm{OM}_{\mathrm{SSA}}\right)$. A brief summary of the emission schemes, shorthand notations adopted 
Table 1. Summary of sea-salt aerosol and marine POA emission schemes used in GEOS-Chem.

\begin{tabular}{lll}
\hline Parameterization & Determining factors & Reference \\
\hline G03 (sea-salt) & $U_{10}^{3.41}, D_{p}$, SST & Gong (2003), Jaeglé et al. (2011) \\
S08 & {$[\operatorname{chl} a]$} & Spracklen et al. (2008) \\
V10 & $U_{10}^{3.41}, D_{p}^{*}$, SST, [chl $\left.a\right]$ & Vignati et al. (2010), Meskhidze et al. (2011) \\
F10 & $U_{10}^{3.41}, D_{p}$, SST, [chl $\left.a\right]$ & Fuentes et al. (2010) \\
L11 & $U_{10}^{3.41}, D_{p}$, SST, [chl $\left.a\right]$ & Long et al. (2011) \\
G11 & $U_{10}^{3.41}, D_{p}$, SST, [chl $\left.a\right], U_{10}$ & Gantt et al. (2011) \\
\hline Sensitivity Study & & \\
\hline Eq. (3) & $U_{10}^{3.41}, D_{p}$, SST, [chl $\left.a\right], U_{10}$ & This work \\
\hline
\end{tabular}

*Aerosol size dependency added by Meskhidze et al. (2011)

in the paper, and the parameters that determine the emission rates for different parameterizations are given in Table 1 . In the first group, Spracklen et al. (2008) used a top-down modeling approach to fit coastal concentrations to emissions linearly related to $[\mathrm{chl} a]$. In the second group linking marine POA emissions with that of sea spray, several studies compared coastal measurements of organic and sea-salt aerosol with parameters such as $[\mathrm{chl} a], 10 \mathrm{~m}$ wind speed $\left(U_{10}\right)$, and aerosol diameter $\left(D_{p}\right)$ to determine the $\mathrm{OM}_{\mathrm{SSA}}$. It was first reported (O'Dowd et al., 2008) and later adjusted (Langmann et al., 2008; Vignati et al., 2010) that the submicron $\mathrm{OM}_{\mathrm{SSA}}$ is linearly related to [chl $a$ ]. Gantt et al. (2011) expanded upon this relationship by adding a negative wind speed relationship and size-dependence to the $\mathrm{OM}_{\mathrm{SSA}}$ calculation. Long et al. (2011) developed a Langmuir relationship between [chl $a$ ] and $\mathrm{OM}_{\mathrm{SSA}}$ and included a sizedependence. Fuentes et al. (2010) showed higher sea spray number emission when phytoplankton exudates are present during laboratory-based bubble bursting experiments. Assuming that the additional emissions are organic in nature and phytoplankton exudates are related to [chl $a$ ], the Fuentes et al. (2010) parameterization is similar to Long et al. (2011) and Gantt et al. (2011) in that the organic mass fraction of sea spray is related to [chl $a$ ] and aerosol size. The resulting submicron emission rates and seasonality predicted by these parameterizations are affected by $U_{10}$ and/or [chl $a$ ] at varying degrees. In this work, we use the latest version of all the available marine POA emission parameterizations and implement them under the same modeling framework to calculate the submicron marine POA source and compare the resulting surface concentrations with aerosol composition measurements from hourly to monthly averaged timescales.

\section{Model and measurements description}

\subsection{GEOS-Chem}

We use version v8-01-01 of the GEOS-Chem (http:// geos-chem.org/) global chemical transport model with $2^{\circ} \times 2.5^{\circ}$ horizontal resolution and 47 vertical levels, driven by GEOS-5 assimilated meteorology from the NASA Global Modeling Assimilation Office (GMAO). The model is run with a full chemistry configuration, which includes $\mathrm{H}_{2} \mathrm{SO}_{4}$ $\mathrm{HNO}_{3}-\mathrm{NH}_{3}$ aerosol thermodynamics (ISORROPIA) coupled to an $\mathrm{O}_{3}-\mathrm{NO}_{\mathrm{x}}$-hydrocarbon-aerosol chemical mechanism (Nenes et al., 1998; Bey et al., 2001; Park et al., 2004). Terrestrial emissions in our simulations include carbonaceous aerosols and sulfur compounds (Park et al., 2004; Heald et al., 2004). Secondary organic aerosol formation from both terrestrial and marine sources is not included in our simulations; therefore primary organic aerosols are the only organic aerosol source. Sea-salt in the model is emitted in two size bins (fine mode ranging from 0.02 to $1.0 \mu \mathrm{m}$ in diameter and coarse mode ranging from 1.0 to $20.0 \mu \mathrm{m}$ in diameter) as a function of a power relationship with $U_{10}$ following the formulation of Gong (2003) and includes the 3 rd order polynomial dependence on sea surface temperature (SST) as described by Jaeglé et al. (2011). Implementation of this SST dependence to sea-salt emissions resulted in improved model prediction of both surface mass concentrations and aerosol optical depth (Jaeglé et al., 2011). Within this model setup, we introduce a hydrophilic and hydrophobic tracer for each marine POA emission scheme. The differences between the hydrophilic and hydrophobic tracers involve depositional processes, with scavenging in convective updrafts and rainout not occurring for hydrophobic tracers (Liu et al., 2001). A detailed description of the various marine POA emission schemes and model treatment of the marine POA tracers is given in Sect. 2.2. With this configuration, year-long GEOS-Chem simulations for the years 2006 and 2009 are performed. In addition to the daily global output of concentrations from the model, we also retain hourly concentrations of the marine POA tracers for the entire 2009 simulation period over the North Atlantic Ocean (model grid centered at $54^{\circ} \mathrm{N}, 10^{\circ} \mathrm{W}$ ) near Mace Head, Ireland. 


\subsection{Marine POA emissions}

Beginning with O'Dowd et al. (2008), all marine POA emission schemes have scaled their emissions to [chl $a$ ] based on the observed correlation with organic aerosol mass concentrations (O'Dowd et al., 2004; Sciare et al., 2009). The differences between the parameterizations, however, is the extent to which other factors besides [chl $a$ ] affect the emission rates. One such factor is the sea spray emission rate, which can vary by several orders of magnitude (de Leeuw et al., 2011). Such variability in sea spray source functions influences the magnitude of marine POA emissions predicted by the individual parameterizations. In order to explicitly compare the different marine POA emission schemes, all the emission parameterizations in this study are implemented under the same GEOS-Chem modeling framework. For the sea spray-based marine POA emissions, the Gong (2003) function that calculates sea-salt emissions in the default version of GEOS-Chem is altered to represent sea spray aerosol containing both sea-salt and organic compounds by accounting for the densities of each constituent. The $\mathrm{OM}_{\mathrm{SSA}}$ calculated for each of the emission parameterizations is applied to the submicron fraction of this combined organic-inorganic sea spray aerosol source function following the method first introduced by O'Dowd et al. (2008). While we acknowledge that some of the marine POA emission parameterizations (Fuentes et al., 2010; Long et al., 2011) were presented in conjunction with the development of novel sea spray source functions and that the magnitude of marine POA emissions is sensitive to the selection of sea spray function, the objective of this study is to describe the spatiotemporal distribution and magnitude of the various marine POA emissions parameterizations relative to each other.

The Spracklen et al. (2008) emissions, whose rates are a linear function of [chl $a$ ], are adjusted to be in the submicron mode by using the suggested submicron/total mass ratio of 0.7 (Spracklen et al., 2008). The Gantt et al. (2011) and Vignati et al. (2010) emissions, which are based on the calculation of OMSSA, are implemented into GEOS-Chem using Eq. (1) and (2) from Meskhidze et al. (2011). For the Fuentes et al. (2010) and Long et al. (2011) parameterizations, an $\mathrm{OM}_{\mathrm{SSA}}$ value was not directly given but had to be calculated. For the Long et al. (2011) emissions, OMSSA is calculated using a conversion from the given organic and sea-salt volume ratio (assuming a density of $1 \mathrm{~g} \mathrm{~cm}^{-3}$ for organics and $2.2 \mathrm{~g} \mathrm{~cm}^{-3}$ for sea-salt (O'Dowd et al., 2008)). In the Fuentes et al. (2010) emissions, $\mathrm{OM}_{\mathrm{SSA}}$ is derived by assuming that the difference in the size-resolved particle number concentration from the sea spray experiments using artificial sea water with and without phytoplankton exudates can be attributed exclusively to marine organic aerosols. The phytoplankton exudate concentration, which controls the difference in the particle number concentration in Fuentes et al. (2010), is calculated by assuming that the $[\operatorname{chl} a]$ is associated with diatoms that are in a low phytoplankton grazing regime (see Fig. 16 from Fuentes et al., 2010 for details). Detailed equations used for all emission schemes are presented in Appendix A.

For all the emissions schemes, submicron marine POA emission rates are determined using monthly averages of the [chl $a$ ] values from the Moderate Resolution Imaging Spectroradiometer (MODIS) aboard the Aqua satellite after regridding (by averaging) from the original

to the $2 \times 2.5^{\circ}$ horizontal grid used in GEOS-Chem. During this regridding, satellite grids that are over land are given a [chl $a$ ] value of 0 while cloud-covered grids are considered as missing values. An organic-mass-to-organic-carbon ratio $(\mathrm{OM} / \mathrm{OC})$ of 1.4 is applied to simulated marine POA to account for the noncarbon component of the organic mass (Desecari et al., 2007; Facchini et al., 2008), and the apparent density of the sea spray is calculated as a function of $\mathrm{OM}_{\mathrm{SSA}}$ according to Gantt et al. (2009). Similar to terrestrial primary organic aerosols in GEOS-Chem, marine POA are emitted as hydrophobic and converted to hydrophilic in the atmosphere with an e-folding time of 1.2 days (Cooke et al., 1999). This is consistent with the observation that freshly emitted submicron marine primary organic aerosols are almost entirely water insoluble consisting of colloids and aggregates (Facchini et al., 2008) but can become more water soluble through atmospheric aging (Rinaldi et al., 2010). In all comparisons with observations, the sum of the hydrophobic and hydrophilic marine POA tracers is used. In the parameterizations based on the calculation of $\mathrm{OM}_{\mathrm{SSA}}$, the marine POA emissions are scaled to the existing sea spray mass emissions without replacement of sea-salt.

\subsection{Observations}

Despite recent interest in the modeling of marine organic aerosol, there are very few observational datasets focusing on marine aerosols (relative to that of terrestrial aerosols) with which to evaluate model performance. Of these, we use datasets that represent very different geographical regions and temporal resolutions. Two datasets (Yoon et al., 2007; Rinaldi et al., 2010) are from Mace Head, Ireland $\left(53.33^{\circ} \mathrm{N}\right.$, $9.90^{\circ} \mathrm{W}$ ), whose aerosol composition is influenced by the biologically productive waters of the North Atlantic Ocean (O'Dowd et al., 2004). Another dataset (Sciare et al., 2009) is from Amsterdam Island $\left(37.80^{\circ} \mathrm{S}, 77.57^{\circ} \mathrm{E}\right)$ in the remote south Indian Ocean, whose aerosol composition is affected by transport from the windy and biologically active Southern Ocean. The surface organic aerosol concentration measurements at Mace Head were taken using a Sierra-Andersen high-volume cascade impactor that divided the aerosols into a fine $\left(D_{50}<1.5 \mu \mathrm{m}\right)$ and coarse $\left(D_{50}>1.5 \mu \mathrm{m}\right)$ modes during clean marine conditions $\left(\mathrm{BC}<50 \mathrm{ng} \mathrm{m}^{-3}\right.$ and wind direction between $180^{\circ}$ and $300^{\circ}$ ) (Yoon et al., 2007; Rinaldi et al., 2010). At Amsterdam Island organic aerosol surface concentration was not separated between sub- and supermicron sizes. An estimate of the submicron fraction of the organic 
aerosol concentration is derived from Claeys et al. (2009) who found that the $\mathrm{PM}_{2.5}$ to $\mathrm{PM}_{10}$ ratio was $\sim 0.41$ at Amsterdam Island. At both Mace Head and Amsterdam Island, the organic aerosols are differentiated as water soluble and water insoluble organic matter (WSOM, WIOM). For the Yoon et al. (2007) and the Sciare et al. (2009) measurements, the WIOM concentrations are compared to surface concentrations of marine POA from GEOS-Chem to minimize the influence of secondary organic aerosols (SOA) which can be classified as WSOM (Ceburnis et al., 2008). For Rinaldi et al. (2010) measurements, in addition to differentiating between WSOM and WIOM, proton nuclear magnetic resonance $\left({ }^{1} \mathrm{HNMR}\right)$ spectroscopy and anion-exchange high performance liquid chromatography (HPLC-TOC) were used for organic chemical characterization. Due to this additional analysis, GEOS-Chem marine POA concentrations are compared to the sum of WIOM and WSOM uncharacterized by the ${ }^{1}$ HNMR and HPLC-TOC analysis. This criterion is based on the discussion in Rinaldi et al. (2010) that these uncharacterized water soluble organic aerosols may be formed by the atmospheric aging of POA to more soluble oxidized organic aerosols.

For the model comparison, we use multi-year monthly averaged WIOM observations at Mace Head and Amsterdam Island for January 2002 to June 2004 (Yoon et al., 2007), and May 2003 to November 2007 (Sciare et al., 2009), respectively. GEOS-Chem results are also compared to "weekly" (8-day) averaged WIOM surface concentrations taken consecutively from January to December 2006 at Amsterdam Island and "weekly" (4- to 14-day depending on the occurrence of clean marine conditions during exposure) averaged WIOM plus uncharacterized WSOM surface concentrations taken quasi-regularly from January to December 2006 at Mace Head (Rinaldi et al., 2010). Comparison of the model output with monthly and weekly averaged OM concentration measurements at two sites with vastly different ocean biological productivity (i.e., Mace Head and Amsterdam Island) can be used to test the ability of parameterization to capture global patterns of marine POA emission as well as emission seasonality. However, a process-based evaluation of marine organic aerosol emissions requires comparison with marine POA fluxes instead of long-term averaged concentrations. Due to the lack of such data, hourly averaged surface concentrations of marine POA predicted from GEOS-Chem are evaluated against a third dataset of high temporal resolution (10 minute resolution averaged hourly) Aerosol Mass Spectrometer (AMS) measurements of the total submicron OM concentration at Mace Head from the year 2009. A detailed description of these measurements, including analysis of a high concentration marine organic aerosol plume and description of AMS sea-salt detection, can be found in Ovadnevaite et al. (2011a) and Ovadnevaite et al. (2012). Of note, organic aerosol AMS data were compared to a SMPS size spectra and a collection efficiency of 0.5 (Matthew et al., 2008) was applied to account for the de- tection losses mainly due to bounce of particles off the vaporizer (Ovadnevaite et al., 2011a). Coincident measurements of wind speed/direction and black carbon (BC) concentration were performed at Mace Head at temporal resolutions of 1 and $5 \mathrm{~min}$, respectively. The AMS measurements are averaged hourly after filtering to only include data in which clean marine conditions persisted for the entire hour. This averaging and filtering is done to be consistent with the hourly GEOS-Chem output of marine POA tracers. We have confidence that this comparison is reasonable because $80 \%$ of the organic aerosol mass measured in clean marine air masses at Mace Head has been shown to be directly associated with ocean biology (Ceburnis et al., 2011). For all the observations, the GEOS-Chem grid cell nearest to the measurement site spatially and temporally is selected for comparison.

\subsection{Sensitivity study}

A sensitivity study is conducted to explore the $\mathrm{OM}_{\mathrm{SSA}}$ dependency on [chl $a$ ] and $U_{10}$ in the G11 emissions scheme by scaling the emission values to best represent the monthly averaged observations from Mace Head and Amsterdam Island. The aim of such a study is to create a sea spray-based marine POA emission scheme with improved seasonality. While all marine POA emission schemes can potentially be evaluated for their dependency on [chl $a$ ], the G11 emissions are used in this sensitivity study because of the flexibility in changing the dependencies on both [chl $a$ ] and $U_{10}$. The need for adjustment of the dependency of $\mathrm{OM}_{\mathrm{SSA}}$ on [chl $a$ ] and $U_{10}$ has been shown by several modeling studies (Meskhidze et al., 2011; Westervelt et al., 2012) who found that modeled marine POA concentrations using sea spray-based emissions struggled to capture the observed seasonality. As marine organic aerosol concentrations have been shown to be directly related to the seasonal cycle of [chl $a$ ] and inversely related to $U_{10}$ seasonality (Sciare et al., 2000, 2009; O'Dowd et al., 2004), through trial and error we have tuned the coefficients in Eq. (1) of Gantt et al. (2011) to get better agreement between the model and measurements.

$$
\begin{aligned}
& \mathrm{OM}_{\mathrm{SSA}}\left(\operatorname{chl} a, \mathrm{U}_{10}, D_{p}\right)= \\
& \frac{\left(\frac{1}{1+\exp \left(X(-2.63[\operatorname{chl} a])+X\left(0.18\left(U_{10}\right)\right)\right.}\right)}{1+0.03 \exp \left(6.81 D_{p}\right)}+\frac{0.03}{1+\exp \left(X(-2.63[\operatorname{chl} a])+X\left(0.018\left(U_{10}\right)\right)\right.}(1)
\end{aligned}
$$

In this formulation, an $X$ value greater than 1 enhances both the positive dependence of OMSSA on $[\mathrm{chl} a]$ and negative dependence of $\mathrm{OM}_{\mathrm{SSA}}$ on $U_{10}$.

\section{Results}

\subsection{Emissions}

Multi-year (2006 and 2009) averaged emission rates for submicron sea-salt aerosol (G03) and the five different marine 
Table 2. GEOS-Chem annual average global sea-salt and marine POA emissions and zonal percentage contributions.

\begin{tabular}{lrrrr}
\hline Parameterization & Global mass & \multicolumn{3}{c}{ Percentage Contribution to Global Emissions } \\
\cline { 3 - 5 } & $(\mathrm{Tg})$ & $90^{\circ} \mathrm{S}-31^{\circ} \mathrm{S}$ & $31^{\circ} \mathrm{S}-31^{\circ} \mathrm{N}$ & $31^{\circ} \mathrm{N}-90^{\circ} \mathrm{N}$ \\
\hline G03 (sea-salt) & 73.6 & 38.8 & 45.1 & 16.1 \\
S08 & 8.3 & 25.5 & 41.2 & 33.3 \\
V10 & 2.9 & 39.0 & 39.1 & 21.8 \\
F10 & 0.1 & 38.9 & 33.9 & 27.2 \\
L11 & 11.9 & 38.9 & 44.2 & 16.9 \\
G11 & 2.9 & 29.2 & 51.3 & 19.5 \\
Eq. (3) & 6.3 & 22.9 & 45.4 & 31.8 \\
\hline
\end{tabular}

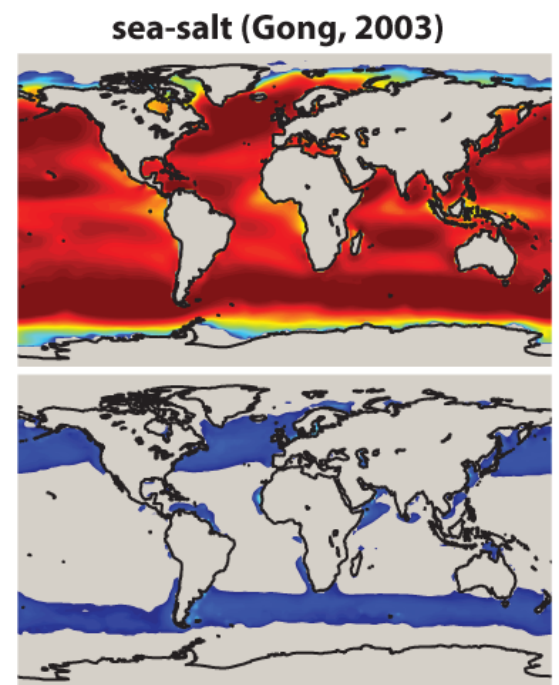

Fuentes et al. (2010)

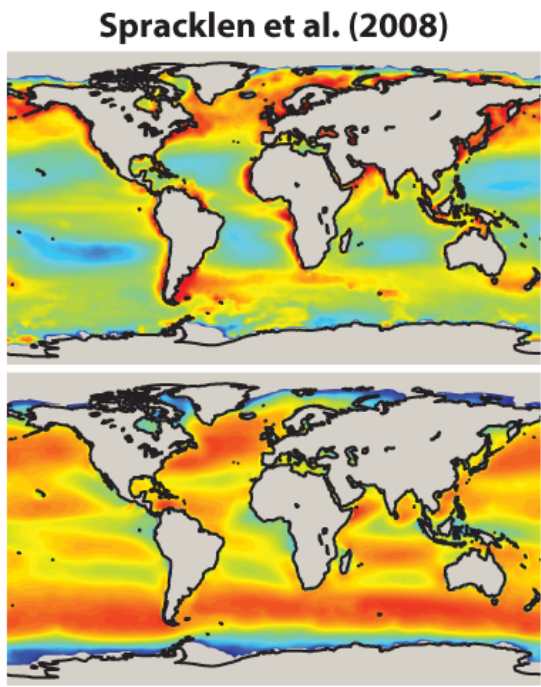

Long et al. (2011)

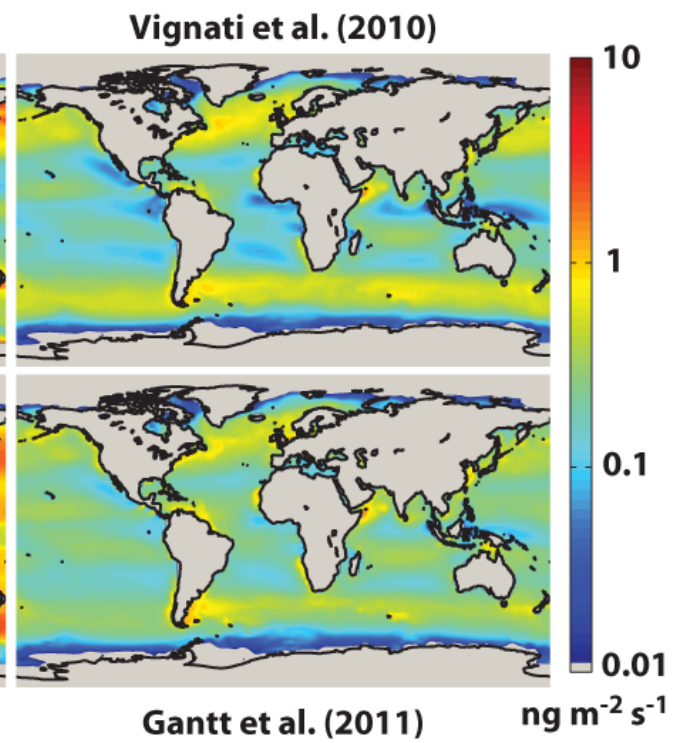

Fig. 1. Annual average submicron emissions in units of $\mathrm{ng} \mathrm{m}^{-2} \mathrm{~s}^{-1}$ of sea-salt (Gong, 2003) and marine POA from the five emission schemes.

POA emission schemes are shown in Fig. 1. The main differences between S08, G11, and the other marine POA emission schemes are in the location of the highest emissions rates and the global magnitude of the emissions. For the S08 scheme, high emission rates occur along the productive coastal and open ocean (equatorial and the high-latitude ocean) upwelling regions. The F10, V10, and L11 schemes predict highest emissions over the windy/productive highlatitude oceans similar to that of sea-salt aerosol, while the G11 scheme predicts high emissions over the both coastal upwelling regions and high-latitude oceans. Comparison of the latitudinal percentage contributions to the marine POA emissions (Table 2) highlights this difference; the S08 (based entirely on [chl $a$ ]) and G11 (based on a combination of [chl $a$ ] and $U_{10}$ ) schemes have a considerable percentage of their emissions from the moderately windy equatorial and northern Atlantic and Pacific Ocean while the F10, V10, and L11 emissions schemes are like sea-salt aerosols in that they have a relatively higher percentage of their emissions occurring in the Southern Ocean where winds are very strong.
The seasonality of the latitudinal contributions to the total marine POA emissions (Table S1) is also different between S08 and the sea spray-based schemes, with S08 having larger seasonal differences than the sea spray-based schemes over mid to high latitude oceanic regions. For all parameterizations, a lack of seasonality in [chl $a$ ] and $U_{10}$ (Fig. S1) and large ocean surface area results in uniform and relatively high percentage contributions of marine organics from low latitude oceanic regions to the total marine POA emission estimates (Table S1). Table 2 shows that the magnitude of global marine POA emissions is considerably different between the different schemes. On the high end is L11, which at $11.9 \mathrm{Tg} \mathrm{yr}^{-1}$ is more than two orders of magnitude higher than the lowest estimate $\mathrm{F} 10$ at $0.1 \mathrm{Tg} \mathrm{yr}^{-1}$. This very low emission estimate from the F10 scheme results from the fact that nearly all the marine POA emissions (as calculated by the increase in particle number concentration from the addition of phytoplankton exudate to artificial seawater) occur in aerosols $<100 \mathrm{~nm}$ in diameter (Fuentes et al., 2010) and therefore contribute minor mass to submicron particles. The 
Spracklen et al. (2008)

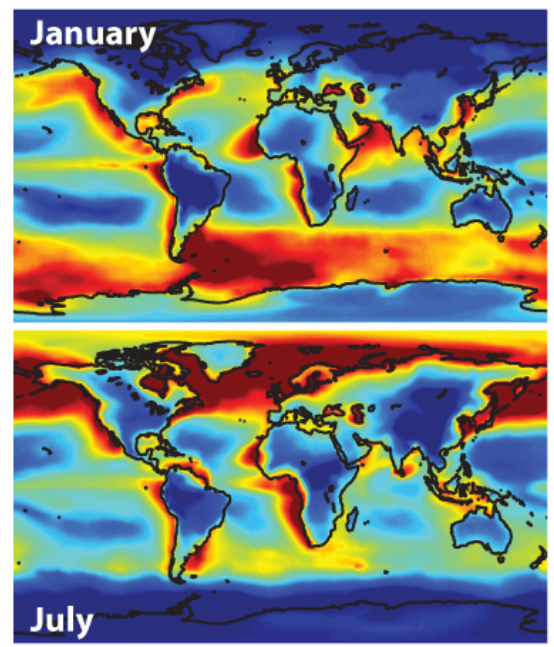

Vignati et al. (2010)

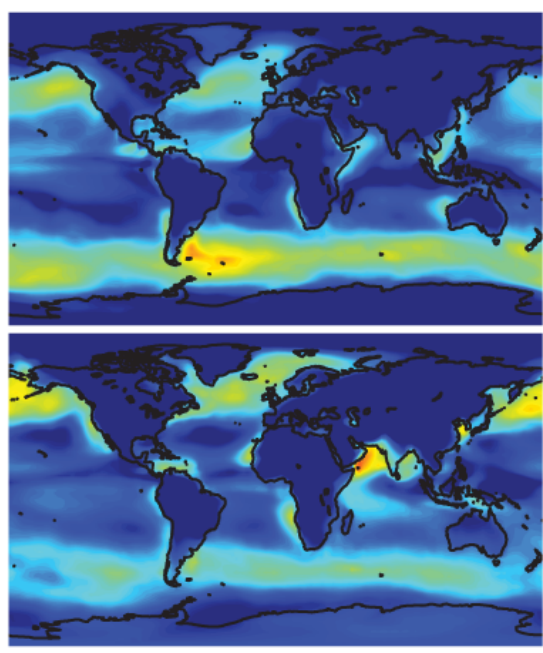

Gantt et al. (2011)

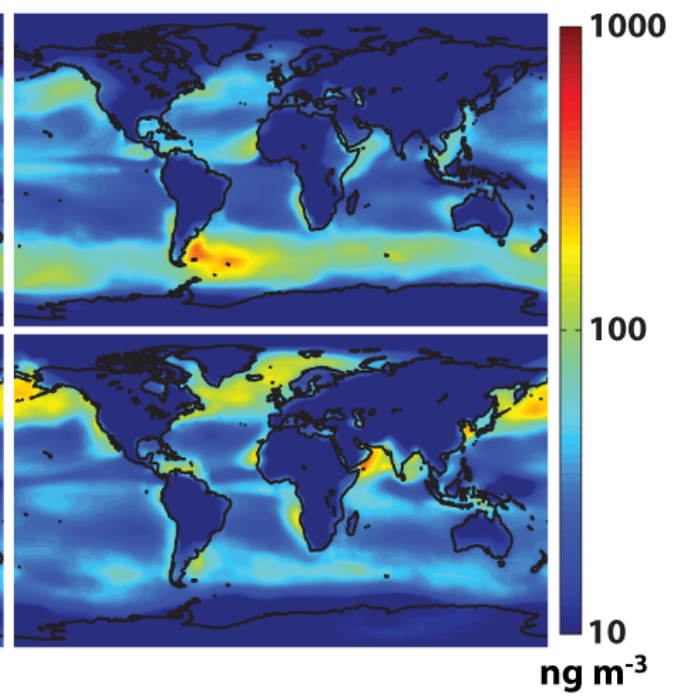

Fig. 2. Average submicron surface concentrations of marine POA in units of $n g \mathrm{~m}^{-3}$ for January (top row) and July (bottom row) from the Spracklen et al. (2008), Vignati et al. (2010), and Gantt et al. (2011) emission schemes.

G11, V10, and S08 emission schemes fall within the range of 3 to $8 \mathrm{Tg} \mathrm{yr}^{-1}$. Although these rates (with the exception of S08) are sensitive to the choice of sea spray function, all but the F10 emissions fall within the $\sim 2-70 \mathrm{Tg} \mathrm{yr}^{-1}$ range of previous global marine POA emission estimates (Langmann et al., 2008; Roelofs, 2008).

\subsection{Global concentrations}

The different emission schemes lead to a large spatiotemporal variation in surface concentrations of marine POA. Figure 2 shows the January and July (2006 and 2009 average) surface concentrations from the simulations using the S08, V10, and G11 emissions schemes. These time periods are shown because they represent the most intense periods for marine biological activities in the Southern Ocean (January) and North Atlantic and North Pacific Oceans (July). The three emission schemes are selected because they have comparable global rates and represent emission schemes dominated by [chl $a$ ] (S08), $U_{10}$ (V10), and a mixture of [chl $a$ ] and $U_{10}$ (G11) (see Table 1). Figure 2 shows that the S08 emissions yield very large seasonal changes in surface POA concentrations over the high productivity oceanic regions (Southern Ocean, northern Atlantic, and northern Pacific Oceans) with high/low concentrations in the summer/winter in high latitude oceanic regions. By comparison, both V10 and G11 emissions schemes show limited seasonal variability in the surface POA concentrations over the high latitudinal oceanic regions with G11 having a somewhat larger seasonal range. Such differences in the model predicted surface POA concentrations are primarily due to the opposing seasonal cycles of $U_{10}$ and [chl $a$ ] produced in V10 and G11 schemes (notice in Fig. S1 that the seasons with the high chlorophyll concentrations are typically associated with low wind speed and vice versa), while emissions from S08 are exclusively dependent on [chl $a$ ]. Figure 2 also shows large differences between the three emission schemes over the coastal and equatorial Pacific upwelling regions, where S08 predicts much higher concentrations throughout the year compared to V10 and G11.

\subsection{Comparison with measurements}

\subsubsection{Monthly and weekly mean values}

Observations of monthly averaged WIOM surface concentrations reveal distinct seasonal cycles for both Mace Head and Amsterdam Island (charts on left column of Fig. 3), with the highest values in the summer and lowest in the winter. When comparing these observations to the predicted concentrations, this Figure shows the mixed ability of the five emissions schemes to replicate the seasonality in marine POA surface concentrations. According to Table 3, the S08 simulation best captures the seasonal cycle with a linear correlation coefficient of 0.81 and 0.50 at Mace Head and Amsterdam Island, respectively. For completeness, it should be noted that the [chl $a$ ] coefficient used in S08 was specifically designed for GEOS-Chem by matching modeled and observed organic aerosol concentrations at Mace Head and Amsterdam Island among other sites and therefore is expected to yield good agreement with the observations. S08 also reproduces the magnitude of the observed concentrations at Mace Head, with a normalized mean bias (NMB) of $<1 \%$. The overprediction of concentrations at Amsterdam Island 

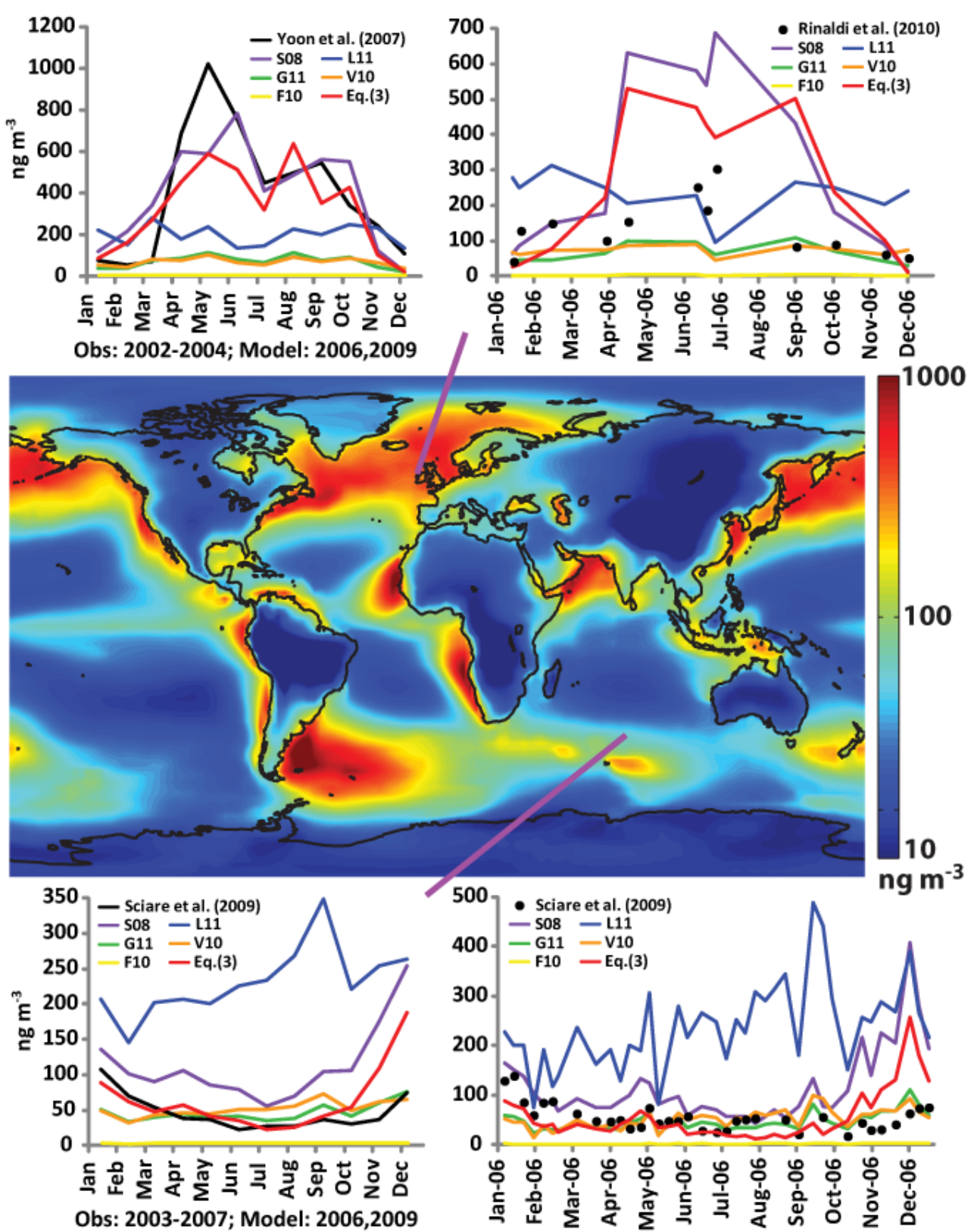

Fig. 3. Multi-year average submicron surface concentration of marine POA using the Eq. (3) emissions with the top and bottom charts comparing the multi-year monthly average (left column) and 2006 weekly average (right column) observations of WIOM concentrations with the modeled POA at Mace Head, Ireland and Amsterdam Island, respectively.

by S08 (NMB of $142 \%$ ) is due in part to the differences in the submicron/total mass ratio (0.7) and $\mathrm{PM}_{2.5} / \mathrm{PM}_{10}$ ratio (0.41) used in the S08 emissions and Amsterdam Island observations, respectively. Table 3 shows that the sea spraybased emission schemes underestimate summertime marine POA concentrations at the Mace Head station and overestimate wintertime concentrations (except F10) at Amsterdam Island. At the extremes of the global emission rates, the F10 simulation strongly underpredicts the surface POA concentrations at both sites while L11 strongly overpredicts the con- centrations at Amsterdam Island. The linear regression relationship for measured and model-predicted (using different sea spray-based parameterizations) submicron WIOM concentrations also shows poor correlation. Table 3 shows that out of all sea spray-based source functions G11 (correlation of 0.74 at Mace Head and 0.34 at Amsterdam Island) best captures the seasonal variation in surface POA concentrations. According to Fig. 3 the large negative bias in marine POA predicted at Mace Head by all sea spray-based parameterizations is largely due to the underpredictions in 


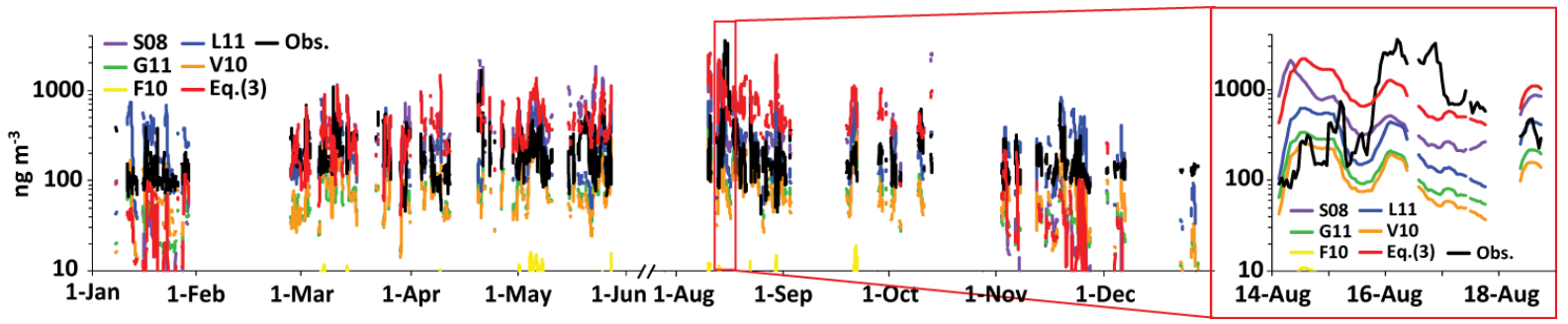

Fig. 4. Comparison of hourly submicron OM concentrations from Mace Head for 2009 during clean marine conditions as measured by an Aerosol Mass Spectrometer (AMS) with hourly modeled marine POA concentrations. The inset shows the comparison for the marine organic aerosol plume event described by Ovadnevaite et al. (2011a). White areas indicate missing data.

Table 3. Comparison of GEOS-Chem marine POA surface concentrations with monthly and weekly average submicron WIOM concentration observations from Mace Head and Amsterdam Island.

\begin{tabular}{|c|c|c|c|c|}
\hline \multirow{2}{*}{$\begin{array}{l}\text { Multi-year } \\
\text { monthly average }\end{array}$} & \multicolumn{2}{|c|}{ Mace Head ${ }^{\mathrm{a}}$} & \multicolumn{2}{|c|}{ Amsterdam Island $^{\text {b }}$} \\
\hline & $\operatorname{NMB}(\%)^{\mathrm{c}}$ & Correlation & $\operatorname{NMB}(\%)^{\mathrm{c}}$ & Correlation \\
\hline S08 & -0.7 & 0.81 & 142.4 & 0.50 \\
\hline V10 & -82.4 & 0.59 & 10.9 & -0.18 \\
\hline F10 & -99.3 & 0.66 & -95.6 & -0.08 \\
\hline L11 & -50.2 & -0.07 & 391.8 & -0.30 \\
\hline G11 & -82.1 & 0.74 & -0.8 & 0.34 \\
\hline Eq. (3) & -18.5 & 0.82 & 17.5 & 0.56 \\
\hline \multicolumn{5}{|c|}{$\begin{array}{l}2006 \text { weekly average } \\
\text { weekly average }\end{array}$} \\
\hline S08 & 132.7 & 0.81 & 108.5 & 0.21 \\
\hline V10 & -44.5 & -0.21 & -4.6 & -0.00 \\
\hline F10 & -97.9 & 0.18 & -96.2 & -0.01 \\
\hline L11 & 75.2 & -0.64 & 327.3 & -0.00 \\
\hline G11 & -49.9 & 0.37 & -15.7 & 0.23 \\
\hline Eq. (3) & 94.6 & 0.58 & 0.3 & 0.24 \\
\hline
\end{tabular}

summertime concentrations. During the summertime, Mace Head is exposed to marine air masses originating over surface oceans with high $[\mathrm{chl} a]$ but with relatively low wind speeds. It appears that the strong effect of such high levels of [chl $a$ ] on organic aerosol concentrations first described by O'Dowd et al. (2004) is not sufficiently well captured in any of the sea spray-based parameterizations due to the strong influence of $U_{10}$. The overestimation of marine POA concentrations in sea-spray based parameterizations at Amsterdam Island during the austral winter is likely due to the strong winds that have an inordinate influence on the predicted marine POA emission rates. This inability of the sea spray-based emission parameterizations to result in surface concentrations with the correct seasonal cycle indicates that the main processes responsible for POA production over the oceans may not be well reproduced by the existing marine POA source functions.
Similar to the multi-year monthly averages, comparison of the weekly averages (WIOM from Amsterdam Island and total OM from Mace Head) from 2006 for the two sites reveals that the S08 and G11 emissions best predict the surface concentrations (charts on right column of Fig. 3). While the S08 emissions consistently overpredict the weekly concentrations at both sites (NMB of 132.7 and $108.5 \%$ at Mace Head and Amsterdam Island), the correlations between the observations and predicted concentrations are high relative to the other parameterizations. Table 3 shows that of the sea spray-based emissions, only the G11 emissions lead to predicted concentrations whose correlations with observations are positive for both sites. 
Table 4. Comparison of 2009 hourly GEOS-Chem marine POA surface concentrations and submicron OM observations from Mace Head.

\begin{tabular}{lrrrr}
\hline Parameterization & \multicolumn{2}{c}{ 2009 Hourly Mace Head } & \multicolumn{2}{c}{ Ovadnevaite et al. (2011a) period } \\
\cline { 2 - 5 } & NMB (\%) & Correlation & NMB (\%) & Correlation \\
\hline S08 & 28.2 & 0.19 & -27.6 & -0.40 \\
V10 & -59.2 & 0.08 & -85.0 & -0.15 \\
F10 & -98.3 & 0.11 & -99.4 & -0.13 \\
L11 & 13.0 & 0.03 & -63.2 & -0.20 \\
G11 & -61.9 & 0.16 & -80.7 & -0.25 \\
Eq. (3) & 68.3 & 0.20 & 15.3 & -0.22 \\
\hline
\end{tabular}

\subsubsection{Hourly averaged data}

Hourly averaged total OM concentration measurements from Mace Head reveal considerable variability (see Fig. 4). The correlation between the model-predicted concentrations and measurements are poor, with S08 having the highest correlation (0.19). In terms of magnitude, there is reasonable agreement between the measurements and the predicted concentrations in the summertime (with the exception of F10) while wintertime predictions (with the exception of L11) are underpredicted. It should be noted that the sea spray source function does not seem to be the only cause of the poor model performance as the surface sea-salt concentrations predicted by G03 and measured by the AMS (Ovadnevaite et al., 2012) have a higher correlation (0.36) compared to marine POA.

A case study of marine organic aerosol plume event from biologically-rich North Atlantic waters when organic mass comprised a major fraction of the total submicron nonrefractory aerosol mass allows us to examine how different emissions parameterizations are able to capture an isolated event. This plume, shown as an inset in Fig. 4, occurred between 14 and 18 August 2009 and experienced organic aerosol concentrations of up to $3.8 \mu \mathrm{g} \mathrm{m}^{-3}$ (Ovadnevaite et al., 2011a). Figure 4 and Table 4 show that none of the parameterizations for marine POA emissions were able to capture the magnitude of organic aerosol concentrations or have positive correlations with measurements for this event. The S08 simulation, which has the highest positive correlation with the year-long time series, exhibits the largest negative correlation $(-0.40)$. The inability of the various parameterizations to capture this plume could be due to multiple reasons related to GEOS-Chem, including interpolation of the 3-h average $10 \mathrm{~m}$ wind speed and precipitation, large model grid size $\left(\sim 38000 \mathrm{~km}^{2}\right.$ at Mace Head), and variability in ocean biology not captured by the monthly averaged [chl $a$ ]. Comparison of predicted and observed sea-salt concentrations during the plume event enables an evaluation of the uncertainties due to the meteorology and model grid size on the predicted marine POA concentrations. Because predicted and observed sea-salt concentrations have relatively higher correlation $(0.42)$ and short time lag $(\sim 1-h)$, it is unlikely that discrepancies between observed and predicted or- ganic aerosol surface concentrations are related entirely to the model resolution and meteorology. The $\sim 40$-h difference in the peak predicted and observed organic aerosol concentration is likely due to the variability in surface ocean biology and incomplete understanding of the processes controlling marine organic aerosol production. This conclusion is consistent with the reported time lag between offshore [chl $a$ ] and $\mathrm{OM}_{\mathrm{SSA}}$ at Mace Head thought to be related to biological processes responsible for the production of organic material transferable to the atmosphere (Rinaldi et al., 2012).

Scatterplots of the 2009 hourly observed and predicted S08 and G11 concentrations color-coded by wind speed (Fig. 5a and b) give us some insights for the potential weaknesses of the two schemes. This Figure shows that the concentrations predicted by each emission scheme that are outside the 1:2 and 2:1 lines are partially dependent on the wind speed. While not universally true, many of the predicted S08 hourly concentrations that are too low occur during high winds and those that are too high occur during low winds. This observation is consistent with evidence that the NMB for the predicted concentrations are stratified by wind speed (Table S2), with the highest NMB (71.8\%) occurring at low $\left(U_{10}<6 \mathrm{~m} \mathrm{~s}^{-1}\right)$ winds and lowest NMB $(-29.8 \%)$ occurring at high $\left(U_{10}>12 \mathrm{~m} \mathrm{~s}^{-1}\right)$ winds. Because marine POA emissions are likely to be affected by the surface wind speed due to their association with sea spray, source functions based solely on [chl $a$ ] may underestimate the actual emission rates during periods of strong winds. Figure 5 (and Table S2) shows that the marine POA concentrations predicted by G11 are consistently low compared to observations. However, the largest underestimation of concentrations typically occurs during periods of low wind speeds. In general, the NMB of the marine POA concentrations from all sea spray-based source functions are consistently more negative at low winds and less negative at high winds (Table S2). These findings suggest that sea spray-based source functions may have too strong of a wind speed dependence. 

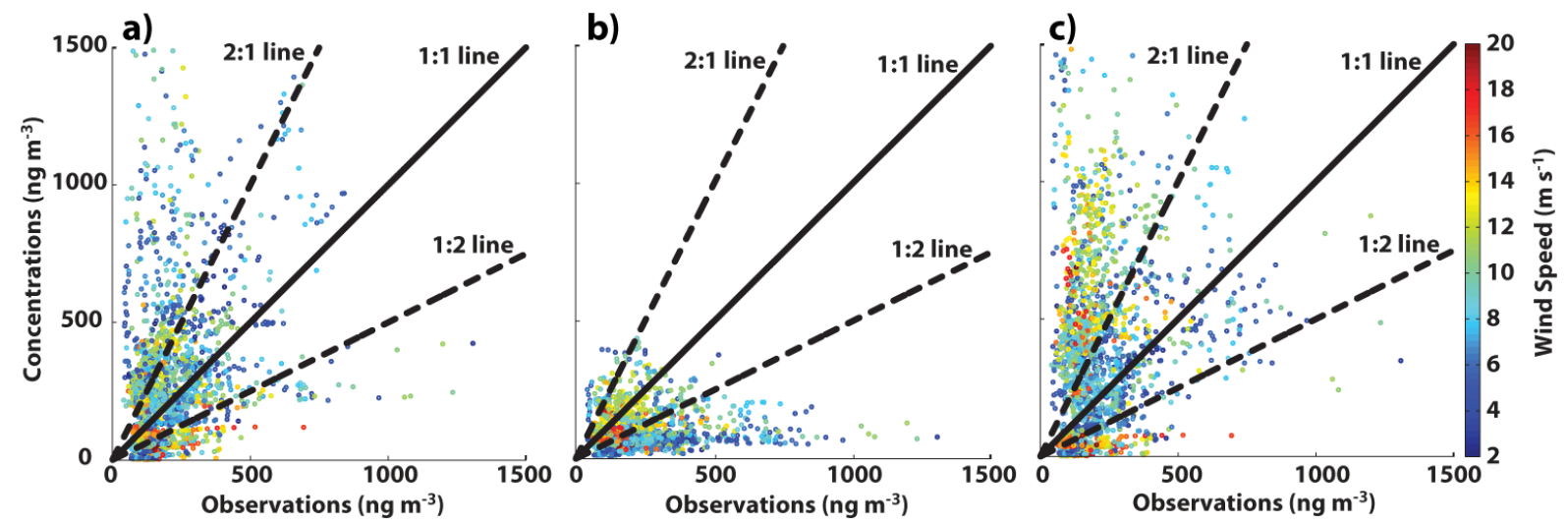

Fig. 5. Scatterplots of the 2009 hourly observed submicron OM concentration and predicted marine POA concentration from the (a) S08, (b) G11, and (c) Eq. (3) emissions at Mace Head. Data is color-coded by the hourly observed wind speed. 23( 1\% of clean marine periods) observational datapoints with concentrations in excess of $1500 \mathrm{ng} \mathrm{m}^{-3}$ were removed.

\section{Sensitivity study}

In a sensitivity study, the OMSSA dependence on $[\operatorname{chl} a]$ and $U_{10}$ is explored by adjusting the $X$ coefficient in Eq. (1) to improve the seasonality and magnitude of the model-predicted concentrations. As previous studies have shown that seasonality is a major weakness of existing marine POA emission schemes, we compare the modeled concentrations to the multi-year monthly averages at Mace Head and Amsterdam Island for the top-down estimate of the $X$ value. Through varying the $X$ coefficient until the best match between modeled and observed concentrations was obtained, it was found that the best correlation (0.82 at Mace Head and 0.56 at Amsterdam Island) occurs with an $X$ value of 3 in Eq. (1) (see Table 3). The updated $\mathrm{OM}_{\mathrm{SSA}}$ calculation is given by Eq. (2):

$$
\begin{aligned}
& \operatorname{OM}_{S S A}\left(\operatorname{chl} a, U_{10}, D_{p}\right)= \\
& \frac{\left(\frac{1}{1+\exp \left(3(-2.63[\operatorname{chl} a])+3\left(0.18\left(U_{10}\right)\right)\right)}\right)}{1+0.03 \exp \left(6.81 D_{p}\right)}+\frac{0.03}{1+\exp \left(3(-2.63[\operatorname{chl} a])+3\left(0.18\left(U_{10}\right)\right)\right)}
\end{aligned}
$$

Despite improved correlation, increase in $X$ value strongly reduced the magnitude of marine POA emissions. The NMB at the two sites were minimized $(-18.5 \%$ and $17.5 \%$ for Mace Head and Amsterdam Island, respectively) by increasing the marine POA emissions by a factor of 6 . The top-down estimate of the marine POA emission rate $\left(E_{\mathrm{POA}}\right)$ derived for GEOS-Chem in the sensitivity study is given by Eq. (3):

$E_{\mathrm{POA}}\left(\operatorname{chl} a, \mathrm{U}_{10}, D_{p}\right)=6 \times V_{\mathrm{SSA}} \times \mathrm{OM}_{\mathrm{SSA}} \times \rho_{\mathrm{SSA}}$

where $V_{\mathrm{SSA}}$ is the volume emissions of sea spray aerosol according to Gong et al. (2003) source function with SST dependence of Jaeglé et al. (2011), $\rho_{\mathrm{SSA}}$ is the apparent density of the sea spray aerosol calculated as a function of OM $\mathrm{MSA}_{\mathrm{SS}}$ according to Gantt et al. (2009), and $\mathrm{OM}_{\mathrm{SSA}}$ is given in Eq. (2).
Global submicron marine POA emissions simulated using Eq. (3) total $6.3 \mathrm{Tg} \mathrm{yr}^{-1}$, with a predicted multi-year annual average surface concentration distribution shown in the map in Fig. 3 that are highest in the biologically productive regions of the northern and southern Atlantic Ocean. Figure 3 shows that after tuning the coefficients, marine POA concentration distribution is similar to that of S08 with slightly better NMB and correlation (see Table 3). However, as the Eq. (3) is based on the model comparison with measurements, the factor of 6 increase in the emission rate is modeldependent and would likely be lower with a slower atmospheric conversion of marine POA from hydrophobic to hydrophilic or with the selection of sea spray source function with a higher submicron aerosol mass flux.

Because Eq. (3) was developed using multi-year monthly averaged measurements, it is possible to do an evaluation of the emissions using the 2006 weekly observations at Mace Head and Amsterdam Island and the 2009 hourly observations from Mace Head. Comparison of surface marine POA concentrations produced from Eq. (3)-based emissions with the hourly observations (shown in Table 4) reveals slightly improved correlation $(0.20)$ relative to the G11 simulations $(0.16)$ and S08 (0.19) for the entire 2009 period. Despite such improvements, Table 4 shows a negative correlation for the plume event, suggesting that tuning coefficients, while improving the agreement with seasonally and monthly averaged observations of marine organic aerosol, cannot improve the emission mechanism for the existing parameterizations. The scatterplot (see Fig. 5c) of the observed and predicted hourly concentrations from Eq. (3) shows that a large number of data points are still outside the 1:2 and 2:1 lines, although there is little wind speed dependence in the NMB (Table S2). 


\section{Summary and conclusions}

Five marine primary organic aerosol (POA) emissions parameterizations were implemented into the GEOS-Chem chemical transport model and evaluated with observations at different locations and temporal resolutions to examine which processes driving the emissions result in better predictions of surface concentrations. To enable comparison amongst the different emission schemes, the same sea spray source function, surface chlorophyll- $a$ concentration ([chl $a]$ ) and meteorological data were used to drive the emissions. Prognostic model simulations were conducted to identify spatiotemporal differences in emissions and surface concentrations of marine POA for all available emissions parameterizations. Our calculations suggest that marine POA emissions parameterizations exclusively related to [chl $a$ ] (i.e., Spracklen et al., 2008) result in predicted concentrations whose seasonality was most similar to that of the observations. However, it should be noted that the [chl $a$ ] coefficient used in S08 was specifically designed for GEOS-Chem by matching modeled and observed organic aerosol concentrations at Mace Head and Amsterdam Island. Marine POA emissions schemes which calculate the organic mass fraction of sea spray (OMSSA) (Vignati et al., 2010; Fuentes et al., 2010; Long et al., 2011; and Gantt et al., 2011) typically overpredict monthly and weekly average concentrations in the wintertime and underpredict summertime concentrations due to the strong influence of the $1010 \mathrm{~m}$ wind speed $\left(U_{10}\right)$ on the emission rates. Hourly observations at Mace Head, Ireland reveal that the surface concentrations predicted by the various emissions schemes have poor correlations with measurements and have difficulty capturing the magnitude of the observed concentrations. This difficulty of the model to replicate the magnitude of concentrations was particularly evident during a marine organic aerosol plume event described by Ovadnevaite et al. (2011a), where observed concentrations of $>3.0 \mu \mathrm{g} \mathrm{m}^{-3}$ are well above the predicted concentrations. As this marine organic aerosol plume event was associated with high cloud condensation nuclei $(\mathrm{CCN})$ and cloud droplet number concentrations (CDNC) (Ovadnevaite et al., 2011b), the inability of the marine POA emission schemes to capture episodic events suggests that current source functions may have difficulties reproducing the effects of marine biology on cloud microphysical properties. New parameterizations need to be derived that are grounded in physical processes unique to the organic fraction of sea spray aerosol, rather than being constrained by the processes that affect sea spray more generally.

The sensitivity study revealed that enhancing the positive dependency of the $\mathrm{OM}_{\mathrm{SSA}}$ on [chl $a$ ] and negative dependency on $U_{10}$ improves the modeled monthly and weekly average concentrations. A top-down emission scheme developed in this study estimates global marine POA emissions at $6.3 \mathrm{Tg} \mathrm{yr}^{-1}$ and reproduces the observations of marine organic aerosol concentrations at all temporal scale with minimal biases. However, comparison of model-simulated concentrations to marine organic aerosol plume event data showed, that mere tuning of coefficients, without fundamental understanding of the processes controlling marine organic aerosol production did not lead to considerable improvements. To fully assess air quality and climate importance of marine organic aerosol, these new physically-based marine POA source functions need to be evaluated against measurements of marine organic aerosol number and size distribution, $\mathrm{CCN}$ properties, and mixing state.

\section{Appendix A}

\section{Equations}

Final form of the submicron emission parameterizations. Intermediate equations and definitions are omitted for clarity. Constants are replaced by the values used in the simulations.

For the sea-salt emissions from the Gong (2003) parameterization with Jaeglé et al. (2011) sea surface temperature dependence:

$$
\begin{aligned}
& V_{\mathrm{SSA}}\left(U_{10}, D_{p}, T\right)=\left(\frac{\pi}{6} D_{p}^{3}\right) \times\left(0.3+0.1 T-0.0076 T^{2}+0.00021 T^{3}\right) \\
& \qquad\left(1.373 U_{10}^{3.41}\left(\frac{D_{p}}{2}\right)^{-A}\left(1+0.057\left(\frac{D_{p}}{2}\right)^{3.45}\right) \times 10^{1.607 \exp \left(-B^{2}\right)}\right) \\
& A=4.7\left(1+30\left(\frac{D_{p}}{2}\right)\right)^{0.017\left(\frac{D_{p}}{2}\right)^{-1.44}} \\
& B=\left[0.433-\log _{10} \frac{D_{p}}{2}\right] / 0.433 \\
& E_{\text {salt }}=V_{\text {SSA }} \rho_{\text {salt }}
\end{aligned}
$$

For the marine POA emissions from the Spracklen et al. (2008) scheme: 
$E_{\mathrm{POA}}(\operatorname{chl} a)=0.4[\operatorname{chl} a]$

For the marine POA emissions from the Vignati et al. (2010) scheme:

$$
\begin{aligned}
\mathrm{OM}_{\mathrm{SSA}}\left(\operatorname{chl} a, U_{10}, D_{p}\right)= & \frac{0.435[\mathrm{chl} a]+0.138}{1+}+0.03 \exp \left(6.81 D_{p}\right) \\
& +0.03 \times(0.435+[\operatorname{chl} a]+0.138)
\end{aligned}
$$

For the marine POA emissions from the Fuentes et al. (2010) scheme:

$\mathrm{OM}_{\mathrm{SSA}}\left(\operatorname{chl} a, D_{p}\right)=-1\left(\frac{\sum_{i=1}^{4} \frac{\beta_{i, 3}}{\sqrt{2 \pi} \log \sigma_{I}}\left[-\frac{1}{2}\left(\frac{\log \left(D_{p} / \alpha_{i, 1}\right)^{2}}{\log \sigma_{i}}\right)^{2}\right]}{\sum_{i=1}^{4} \frac{N_{T, i}}{\sqrt{2 \pi \log \sigma_{i}}} \exp \left[-\frac{1}{2}\left(\frac{\log \left(D_{p} / D_{p g, i}\right)}{\log \sigma_{i}}\right)^{2}\right]}\right)(\mathrm{A} 7)$

$D_{p g, i}=\alpha_{i, 1}+\alpha_{i, 2} \exp \left(-\alpha_{i, 3} 488[\operatorname{chl} a]\right)$

$N_{T, i}=\beta_{i, 1}(488[\operatorname{chl} a])^{2}+\beta_{i, 2}(488[\operatorname{chl} a])+\beta_{i, 3}$

For the marine POA emissions from the Long et al. (2011) scheme:

$$
\mathrm{OM}_{\mathrm{SSA}}\left(\operatorname{chl} a, D_{p}\right)=1-\frac{1}{1+\left(0.306 D_{p}^{\frac{-2.01 \times 40.0[\mathrm{chl} a]}{1+40.0[\mathrm{chl} a]}} \times \frac{\rho_{\mathrm{org}}}{\rho_{\mathrm{salt}}}\right)}
$$

For the marine POA emissions from the Gantt et al. (2011) scheme:

$$
\begin{aligned}
\mathrm{OM}_{\mathrm{SSA}}\left(\operatorname{chl} a, U_{10}, D_{p}\right) & =\frac{\frac{1}{1+\exp \left(-2.63[\operatorname{chl} a]+0.18 U_{10}\right)}}{1+0.03 \exp \left(6.81 D_{p}\right)} \\
& +\frac{0.03}{1+\exp \left(-2.63[\operatorname{chl} a]+0.18 U_{10}\right)}
\end{aligned}
$$

For all marine POA emission schemes using calculating the $\mathrm{OM}_{\mathrm{SSA}}$ :

$$
\begin{aligned}
E_{\mathrm{POA}}\left(\operatorname{chl} a, U_{10}, D_{p}, T\right)= & V_{\mathrm{SSA}}\left(U_{10}, D_{p}, T\right) \\
& \times \mathrm{OM}_{\mathrm{SSA}}\left(\operatorname{chl} a, U_{10}, D_{p}\right) \times \rho_{\mathrm{SSA}}\left(\operatorname{chl} a, U_{10}, D_{p}\right)
\end{aligned}
$$

\section{Appendix B}

\section{Notation}

[chl $a$ ] chlorophyll- $a$ concentration, $\mathrm{mg} \mathrm{m}^{-3}$

$D_{p} \quad$ Aerosol diameter, $\mu \mathrm{m}$

$D_{p g, i} \quad$ geometric mean diameter for each lognormal mode $\mathrm{i}, \mu \mathrm{m}$

$E_{\mathrm{POA}} \quad$ Marine primary organic aerosol mass emission rate, $\mathrm{ng} \mathrm{m}^{-2} \mathrm{~s}^{-1}$

$E_{\text {salt }} \quad$ Sea-salt mass emission rate, $\mathrm{ng} \mathrm{m}^{-2} \mathrm{~s}^{-1}$

$N_{T, i}$ total particle number for each lognormal mode $\mathrm{i}, \mathrm{cm}^{-3}$

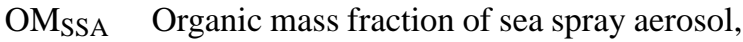
unitless

$T \quad$ Sea surface temperature, ${ }^{\circ} \mathrm{C}$

$U_{10} \quad 10 \mathrm{~m}$ wind speed, $\mathrm{m} \mathrm{s}^{-1}$

$V_{\mathrm{SSA}} \quad$ Sea spray volume emission rate, $\mu \mathrm{m}^{3} \mathrm{~m}^{-2} \mathrm{~s}^{-1}$

$\alpha_{i} \quad$ parameters inferred from exponential regression defining the geometric mean diameter for each lognormal mode $i$ as a function of the diatomaceous $\mathrm{OC}<0.2 \mu \mathrm{m}$ content of seawater, unitless

$\beta_{i} \quad$ parameters inferred from polynomial regression defining the total particle number for each lognormal mode $i$ as a function of the diatomaceous $\mathrm{OC}<0.2 \mu \mathrm{m}$ content of seawater, unitless

$\rho_{\text {org }} \quad$ Marine POA density, $\mathrm{ng} \mu \mathrm{m}^{-3}$

$\rho_{\text {salt }} \quad$ Sea-salt density, $\mathrm{ng}_{\mu \mathrm{m}}{ }^{-3}$

$\rho_{\text {SSA }} \quad$ Sea spray aerosol density, $\mathrm{ng}_{\mu \mathrm{m}^{-3}}$

$\sigma_{i} \quad$ geometric standard deviation for each lognormal mode, unitless

\section{Supplementary material related to this article is available online at: http://www.atmos-chem-phys.net/12/ 8553/2012/acp-12-8553-2012-supplement.pdf.}

Acknowledgements. This research was supported by the Office of Science (BER), US Department of Energy grant No. DEFG02-08ER64508, National Science Foundation grant No. ATM0826117, and National Aeronautics \& Space Administration (NASA) through grant no NNX11AG72G. The authors would like to thank Dr. Daniel Jacob and the Harvard University Atmospheric Chemistry Modeling Group for providing the base model GEOSChem used during our research. BG is also supported by the NASA Earth and Space Science Fellowship (NESSF) Program. EPA Ireland is acknowledged for Research Support at Mace Head. We thank reviewer Daniel Westervelt (CMU) and an anonymous reviewer for their helpful comments which have improved this manuscript. 
Edited by: C. Hoose

\section{References}

Bey, I., Jacob, D. J., Yantosca, R. M., Logan, J. A., Field, B., Fiore, A. M., Li, Q., Liu, H., Mickley, L. J., and Schultz, M.: Global modeling of tropospheric chemistry with assimilated meteorology: Model description and evaluation, J. Geophys. Res., 106, 23073-23095, 2001.

Bigg, E. K. and Leck C.: The composition of fragments of bubbles bursting at the ocean surface, J. Geophys. Res., 113, D11209, doi:10.1029/2007JD009078, 2008.

Ceburnis, D., O’Dowd, C. D., Jennings, G. S., Facchini, M. C., Emblico, L., Decesari, S., Fuzzi, S., and Sakalys, J.: Marine aerosol chemistry gradients: elucidating primary and secondary processes and fluxes, Geophys. Res. Lett., 35, L07804, doi:10.1029/2008GL033462, 2008.

Ceburnis, D., Garbaras, A., Szidat, S., Rinaldi, M., Fahrni, S., Perron, N., Wacker, L., Leinert, S., Remeikis, V., Facchini, M. C., Prevot, A. S. H., Jennings, S. G., Ramonet, M., and O'Dowd, C. D.: Quantification of the carbonaceous matter origin in submicron marine aerosol by ${ }^{13} \mathrm{C}$ and ${ }^{14} \mathrm{C}$ isotope analysis, Atmos. Chem. Phys., 11, 8593-8606, doi:10.5194/acp-11-85932011, 2011.

Claeys, M. B., Wang, W., Vermeylen, R., Kourtchev, I., Chi, X., Farhat, Y.J., Surratt, D., Gómez-González, Y., Sciare, J., and Maenhaut, W.: Chemical characterisation of marine aerosol at Amsterdam Island during the austral summer of 2006-2007, J. Aerosol Sci., 41, 13-22, doi:10.1016/j.jaerosci.2009.08.003, 2009.

Cooke, W. F., Liousse, C., Cachier, H., and Feichter, J.: Construction of a $1^{\circ} \times 1^{\circ}$ fossil fuel emission data set for carbonaceous aerosol and implementation and radiative impact in theECHAM4 model, J. Geophys. Res., 104, 22137-22162, 1999.

Decesari, S., Facchini, M. C., Mircea, M., Cavalli, F., Emblico, L., Fuzzi, S., Moretti, F., and Tagliavini, E.: Source attribution of water-soluble organic aerosol by nuclear magnetic resonance spectroscopy, Environ. Sci. Technol., 41, 2479-2484, 2007.

Facchini, M. C., Rinaldi, M., Decesari, S., Carbone, C., Finessi, E., Mircea, M., Fuzzi, S., Ceburnis, D., Flanagan, R., Nilsson, E., de Leeuw, G., Martino, M., Woeltjen J., and O'Dowd, C. D.: Primary sub-micron marine aerosol dominated by insoluble organic colloids and aggregates, Geophys. Res. Lett., 35, L17814, doi:10.1029/2008GL034210, 2008.

Fuentes, E., Coe, H., Green, D., de Leeuw, G., and McFiggans, G.: On the impacts of phytoplankton-derived organic matter on the properties of the primary marine aerosol - Part 1: Source fluxes, Atmos. Chem. Phys., 10, 9295-9317, doi:10.5194/acp-10-92952010, 2010.

Fuentes, E., Coe, H., Green, D., and McFiggans, G.: On the impacts of phytoplankton-derived organic matter on the properties of the primary marine aerosol - Part 2: Composition, hygroscopicity and cloud condensation activity, Atmos. Chem. Phys., 11, 25852602, doi:10.5194/acp-11-2585-2011, 2011.

Gantt, B., Meskhidze, N., and Kamykowski, D.: A new physicallybased quantification of marine isoprene and primary organic aerosol emissions, Atmos. Chem. Phys., 9, 4915-4927, doi:10.5194/acp-9-4915-2009, 2009.
Gantt, B., Meskhidze, N., Facchini, M. C., Rinaldi, M., Ceburnis, D., and O'Dowd, C. D.: Wind speed dependent size-resolved parameterization for the organic mass fraction of sea spray aerosol, Atmos. Chem. Phys., 11, 8777-8790, doi:10.5194/acp-11-87772011, 2011.

Gantt, B., Xu, J., Meskhidze, N., Zhang, Y., Nenes, A., Ghan, S. J., Liu, X., Easter, R., and Zaveri, R.: Global distribution and climate forcing of marine organic aerosol - Part 2: Effects on cloud properties and radiative forcing, Atmos. Chem. Phys. Discuss., 12, 7453-7474, doi:10.5194/acpd-12-7453-2012, 2012.

Gong, S.: A parameterization of sea-salt aerosol source function for sub- and super-micron particles, Global Biogeochem. Cy., 17, 1097-1103, 2003.

Heald, C. L., Jacob, D. J., Jones, D. B. A., Palmer, P. I., Logan, J. A., Streets, D. G., Sachse, G. W., Gille, J. C., Hoffman, R. N., and Nehrkorn, T.: Comparative inverse analysis of satellite (MOPITT) and aircraft (TRACE-P) observations to estimate Asian sources of carbon monoxide, J. Geophys. Res., 109, D23306, doi:10.1029/2004JD005185, 2004.

Jaeglé, L., Quinn, P. K., Bates, T. S., Alexander, B., and Lin, J.-T.: Global distribution of sea salt aerosols: new constraints from in situ and remote sensing observations, Atmos. Chem. Phys., 11, 3137-3157, doi:10.5194/acp-11-3137-2011, 2011.

Langmann, B., Scannell, C., and O'Dowd, C.: New directions: Organic matter contribution to marine aerosols and cloud condensation nuclei, Atmos. Environ., 42, 7821-7822, 2008.

Lapina, K., Heald, C. L., Spracklen, D. V., Arnold, S. R., Allan, J. D., Coe, H., McFiggans, G., Zorn, S. R., Drewnick, F., Bates, T. S., Hawkins, L. N., Russell, L. M., Smirnov, A., O’Dowd, C. D., and Hind, A. J.: Investigating organic aerosol loading in the remote marine environment, Atmos. Chem. Phys., 11, 8847-8860, doi:10.5194/acp-11-8847-2011, 2011.

Liu, H., Jacob, D. J., Bey, I., and Yantosca, R. M.: Constraints from $210 \mathrm{~Pb}$ and $7 \mathrm{Be}$ on wet deposition and transport in a global threedimensional chemical tracer model driven by assimilated meteorological fields, J. Geophys. Res., 106, 12 109-12 128, 2001.

Long, M. S., Keene, W. C., Kieber, D. J., Erickson, D. J., and Maring, H.: A sea-state based source function for size- and composition-resolved marine aerosol production, Atmos. Chem. Phys., 11, 1203-1216, doi:10.5194/acp-11-1203-2011, 2011.

Matthew, B. M., Middlebrook, A. M., and Onasch, T. B.: Collection Efficiencies in an Aerodyne Aerosol Mass Spectrometer as a Function of Particle Phase for Laboratory Generated Aerosols, Aerosol Sci. Technol., 42, 884-898, doi:10.1080/02786820802356797, 2008.

Meskhidze, N., Xu, J., Gantt, B., Zhang, Y., Nenes, A., Ghan, S. J., Liu, X., Easter, R., and Zaveri, R.: Global distribution and climate forcing of marine organic aerosol: 1 . Model improvements and evaluation, Atmos. Chem. Phys., 11, 11689-11705, doi:10.5194/acp-11-11689-2011, 2011.

Nenes, A., Pandis, S. N., and Pilinis, C.: ISORROPIA: A new thermodynamic equilibrium model for multiphase multicomponent inorganic aerosols, Aquat. Geochem., 4, 123-152, 1998.

O’Dowd, C. D., Facchini, M. C., Cavalli, F., Ceburnis, D., Mircea, M., Decesari, S., Fuzzi, S., Yoon, Y. J., and Putaud, J. P.: Biogenically driven organic contribution to marine aerosol, Nature, 431, 676-680, 2004.

O’Dowd, C. D., Langmann, B., Varghese, S., Scannell, C., Ceburnis, D., and Facchini, M.: A combined organic-inorganic 
sea-spray source function, Geophys. Res. Lett., 35, L01801, doi:10.1029/2007GL03033, 2008.

Ovadnevaite, J., O'Dowd, C., Dall'Osto, M., Ceburnis, D., Worsnop, D. R., and Berresheim, H.: Detecting high contributions of primary organic matter to marine aerosol: a case study, Geophys. Res. Lett., 38, L02807, doi:10.1029/2010GL046083, 2011a.

Ovadnevaite, J., Ceburnis, D., Martucci, G., Bialek, J., Monahan, C., Rinaldi, M., Facchini, M. C., Berresheim, H., Worsnop, D. R., and O'Dowd, C. D: Primary marine organic aerosol: A dichotomy of low hygroscopicity and high CCN activity, Geophys. Res. Lett., 38, L21806, doi:10.1029/2011GL048869, 2011 b.

Ovadnevaite, J., Ceburnis, D., Canagaratna, M., Berresheim, H., Bialek, J., Martucci, G., Worsnop, D. R., and O'Dowd, C.: On the effect of wind speed on submicron sea salt mass concentrations and source fluxes, J. Geophys. Res., 117, D16201, doi:10.1029/2011JD017379, doi:10.1029/2011JD017379, 2012.

Park, R. J., Jacob, D. J., Field, B. D., Yantosca, R. M., and Chin, M.: Natural and transboundary pollution influences on sulfate-nitrate-ammonium aerosols in the United States: implications for policy, J. Geophys. Res., 109, D15204, doi:10.1029/2003JD004473, 2004.

Rinaldi, M., Decesari, S., Finessi, E., Giulianelli, L., Carbone, C., Fuzzi, S., O’Dowd, C. D., Ceburnis, D., and Facchini, M. C.: Primary and secondary organic marine aerosol and oceanic biological activity: Recent results and new perspectives for future studies, Adv. Meteorol., 2010, 310682, doi:10.1155/2010/310682, 2010.

Rinaldi, M., Fuzzi, S., Decesari, S., Marullo, S., Santoleri, R., Provenzale, A., von Hardenberg, J., Ceburnis, D., O’Dowd, C. D., and Facchini, M. C.: Is chlorophyll- $a$ the best surrogate for organic matter enrichment in submicron primary marine aerosol?, J. Geophys. Res., submitted, 2012.
Roelofs, G. J.: A GCM study of organic matter in marine aerosol and its potential contribution to cloud drop activation, Atmos. Chem. Phys., 8, 709-719, doi:10.5194/acp-8-709-2008, 2008.

Sciare, J., Mihalopoulos, N., and Dentener, F. J.: Interannual variability of atmospheric dimethylsulfide in the southern Indian Ocean, J. Geophys. Res., 105, 26369-26378, 2000.

Sciare, J., Favez, O., Sarda-Estève, R., Oikonomou, K., Cachier, H., and Kazan, V.: Long-term observations of carbonaceous aerosols in the Austral Ocean atmosphere: Evidence of a biogenic marine organic source, J. Geophys. Res., 114, D15302 doi:10.1029/2009JD011998, 2009.

Spracklen, D. V., Arnold, S. R., Carslaw, K. S., Sciare, J., and Pio, C.: Globally significant oceanic source of organic carbon aerosol, Geophys. Res. Lett., 35, L12811, doi:10.1029/2008GL033359, 2008.

Vignati, E., Facchini, M. C., Rinaldi, M., Scannell, C., Ceburnis, D., Sciare, J., Kanakidou, M., Myriokefalitakis, S., Dentener, F., and O'Dowd, C. D.: Global scale emission and distribution of seaspray aerosol: sea-salt and organic enrichment, Atmos. Environ., 44, 670-677, 2010.

Westervelt, D. M., Moore, R. H., Nenes, A., and Adams, P. J.: Effect of primary organic sea spray emissions on cloud condensation nuclei concentrations, Atmos. Chem. Phys., 12, 89-101, doi:10.5194/acp-12-89-2012, 2012.

Yoon, Y. J., Ceburnis, D., Cavalli, F., Jourdan, O., Putaud, J. P., Facchini, M. C., Decesari, S., Fuzzi, S., Sellegri, K., Jennings, S. G., and O'Dowd, C. D.: Seasonal characteristics of the physicochemical properties of North Atlantic marine atmospheric aerosols, J. Geophys. Res. Atmos., 112, D04206, doi:10.1029/2005JD007044, 2007. 